\author{
Robertas Stunžinas \\ Mykolas Romeris University \\ Vilnius
}

\title{
Folk terms of Slavic origin for traditional Lithuanian buildings and their parts
}

Folk terminology is a broad layer of common lexis and an important source of scientific terminology. The importance of folk terminology in the process of creating scientific terminology has been emphasised by the initiator of Lithuanian terminology theory philosopher Stasys Šalkauskis (1886-1941). He stated that spoken language is the main source of terminology and there is no necessity to create new words nor borrow them if it is possible to adopt words from spoken language. The philosopher pointed out that words from the spoken language are not only the most plentiful but also most perspicuous source of scientific terminology (Šalkauskis, 1991, p. 55).

Folk terms for building form a specific and interesting layer of lexis. They are closely related to scientific terms and characterized by a variety of linguistic expression, figurativeness, synonymy, polysemy, and variation ${ }^{1}$. Folk terminology for building is closely related to scientific terminology that started to develop in the $19^{\text {th }}$ century and has been borrowing terms from spoken language. For example, terms borrowed from spoken language are used in first Lithuanian periodical publications about buildings: grịczia 'house’2 Uk 1891 IV 173, kakalis 'stove' Uk 1891 IV 173, kalkiai 'lime'

${ }^{1}$ Lithuanian folk terminology of building was researched in doctoral thesis Folk terms for building prepared by the author of this article.

${ }^{2}$ Examples are taken from periodical publications Ukinikas: lietuviszkas laikrasztis, paskirtas reikalams ukinįku (Ragainè, 1880-1905) and Medega statant trobas // Auszra (Ragainè, 1884, No. 1-2). 
Med 1884 I-II 56, langas 'window' Uk 1890 II 22, lubos 'ceiling' Uk 1891, stogo czerpēs 'roof tiles' Med 1884 I-II 56.

In this article, folk terms of Slavic origin that denote traditional Lithuanian buildings and their parts are analyzed. The aim is to give an overview of folk terms of Slavic origin naming houses, farm buildings and their parts, and to identify semantic relations of terms - synonymy and polysemy. The article deals with more than 130 Slavisms. The material has been gathered from main sources of spoken language and folk terminology - common dictionaries, dictionaries and atlases of dialects: Lietuviu kalbos žodynas (Dictionary of the Lithuanian Language) (LKŽe), Lietuviu kalbos atlasas (Atlas of the Lithuanian Language, vol. 1) (LKA I), Druskininku tarmès žodynas (Dictionary of Druskininkai Sub-dialect) (DrskŽ), Kaltanenu šnektos žodynas (Dictionary of Kaltanènai Sub-dialect) (KltŽ), Kazlų Rūdos šnektos žodynas (A-M) (Dictionary of Kazlų Rūda Sub-dialect (vol. 1) (KzRŽ I), Kupiškènu žodynas (A-H) (Dictionary of Kupiškènai (vol. 1) (KpŽ), Lazūnu tarmès žodynas (Dictionary of Lazūnai Sub-dialect (LzŽ), Šiaurès rytu dūnininkų šnektu žodynas (Dictionary of North-Estern Dünininkai Sub-dialectes (DūnŽ), Zanavykų šnektos žodynas (Dictionary of Zanavykai Sub-dialect (vol. 1-3) (ZanavŽ 1-3).

Slavic loanwords amount to a significant part of all folk terminology of building. About one sixth of all folk terms that name buildings and their constructions, building materials and building instruments are of Slavic origin. Loanwords from Slavic languages are used two times more often than German loanwords and fifteen times more often than Latvian loanwords ${ }^{3}$.

Buildings of traditional Lithuanian homestead are denoted by 42 Slavisms and half of them are names of houses. Five synonymous terms of Slavic origin are used as generic names: gryčia (Belarusian гры дніu, $a^{4}$ ) LKA I 34, KpŽ 733, grinyčia (Belarusian грыдніиа) LKŽe, budavoné (Polish budowanie) LKŽe, budinkas (Polish budynek, Belarusian будынак) LKŽe, DrskŽ 44, KzRŽ I 89, KpŽ 244, LzŽ 41, gaspada (Belarusian госnода, Russian госnода ЭСБМ, 1985, p. 70, Polish gospoda) LKŽe. Although all terms mentioned have a similar meaning not all of them can be treated as absolute synonyms. Traditional Lithuanian houses have construction differences as they are used in different ethnographic regions. Historically three types of living houses can be distinguished: 1) troba (Lith.) (in the ethnographic region of Žemaitija (Samogitia), 2) pirkia (Lith.), gryčia (Slav.) (in Aukštaitija (Highland) 3) grinčia (Slav.), pirkčia (Lith.), stuba (Germ.) (in Suvalkija (Sudovia) (LEB, 1964, p. 216) ${ }^{5}$. Traditional Samogitian house is

${ }^{3}$ Proportions are taken from doctoral thesis.

${ }^{4}$ Etymology shown in brackets is taken from primary sources of folk terms, i. e. dictionaries and atlases, or from additional sources. If additional reference in brackets is not presented etymology is taken from term source. References of additional sources are presented at the end of article.

${ }^{5}$ Due to word spread folk terms from regions of origin can be also found in other areas of Lithuania. For example, Lith. troba is also used in Aukštaitija (Highland): Mano troba buvo pakalnén 
characterized by long and large building and low walls with paling. Samogitian house has a complex layout of 5-15 rooms. Traditional houses in the ethnographic region of Aukštaitija have narrow and long buildings, average height walls, straw roof and a porch constructed in front of entrance. Houses have a simple plan and the inside is divided into three main parts by cross walls. Houses in Suvalkija have common features with Samogitian houses as well as houses from the ethnographic region of Aukštaitija (LEB, 1964, pp. 216-224). The Slavisms mentioned also are naming different types of houses in different regions of Lithuania. Gryčia is the traditional name of house of Eastern Aukštaitija, grinyčia generally is used in Žemaitija, gaspada - in Suvalkija. The term budinkas can be treated as a common term as it is used in all ethnographic regions of Lithuania. The majority of terms have more than one meaning. The term gryčia also is used as a specific term and has the meaning of an old and small house, moreover it is used to denote various parts of houses. The term grinyčia has additional meaning of smokehouse and underground house.

A total of 13 Slavisms are used as specific names and indicate types of living houses according to quality, construction, and size. More than a half of terms denote house according to quality features. 6 synonymic terms denote poor old house: balaganas (Russian балаган Fraenkel, 1962, p. 31) KpŽ 138, gryčia (Belarusian грыдніца LKA I 34) LKA I 34, kalupka (Polish chałupa) LKŽe, kamurka (Polish komórka, Russian каморка) LKŽe, kaniūkšle (Belarusian канюшная) LKŽe, kiža (Belarusian xiжа, dial. Russ. хижа Фасмер, 1973, pp. 235-236, Polish chyża) LKŽe. Slavisms kaniūkšlé and kamurka can be treated as metaphorical having primary meanings: 'stable' and 'pantry'. In these cases metaphorization of meaning could have occured because of the emotional associations made by these objects.

A luxurious house is denoted by two synonymic terms: kamenyčia (Russian dial. ка́менииа ЭССЯ, 1983, p. 131, Polish kamienica) 'luxurous brick house' LKŽe, KaltŽ 98, pakajai (old Russian nокоu, Polish pokój Фасмер, 1987, p. 305) ZanavŽ 2311. Three terms name a house according to construction features: two terms are used for brick house and one term - for clay house: mūras (Polish mur) 'brick house ${ }^{6}$ ' LKŽe, DrskŽ 217, KzRŽ I 523, LzŽ 169, ZanavŽ 2 221, kaminyčia (Polish kamienica) 'brick house’ LKŽe, DrskŽ 135; lepenka (Russian лепень, Фасмер, 1986, p. 483, Polish lepianka) 'clay house' LKŽe. Two specific terms name house according to size: gryčia (Belarusian грыдніиа) 'small house' LKA I 34, LKŽe, stadala (Belarusian стадола, Polish stodoła) 'big house' LKŽe. The term stadala can be treated as metaphorical as its primary meaning is 'inn'.

(Druskininkai) LKŽe. Grinčia can be found not only in Sudovia (Suvalkija), but also in other regions of Aukštaitija (Highland): Eik grinčion - sušalsi (Bagaslaviškis, Širvintos DC). Nèra grinčios be dūmu (Joniškèlis, Pasvalys DC) LKŽe.

${ }^{6}$ Explanations are taken from primary sources. 
A bundle of 37 Slavisms denote parts of a house. Nearly one third of the terms (13) denote house sides, annexes and two thirds (24) are names of rooms. Five terms are used to denote house sides. Traditional Samogitian houses have two sides named 'good house' and 'poor house'. 'Poor house' is the non-representative side and serves for everyday family life, whereas 'good house' is the representative side and is used for guest accommodation. Term gryčia (Belarusian грыдніца) is used to name both generic and specific concepts and has two meanings: 'house side' LKA I 34 and 'poor house' LKŽe. 'Good house' is denoted by three synonymous terms: seklyčia (Belarusian святліu a, Polish świetlica) LKŽe, ZanavŽ 3 33, stancija (Polish stancja) LKŽe, kamara (Russian комора, Polish komora Фасмер, 1986, p. 305) LKŽe, KaltŽ 97. Names of house sides are characterized by polysemy and also are used to name rooms, for example: gryčia (Belarusian грыıдніи а LKA I 34) 'bedroom' LKŽe, kamara (Russian комора, Polish komora Фасмер, 1986, p. 305) 'living room' LKŽe, LzŽ 104, seklyčia (Belarusian святліияa, Polish świetlica) 'guest room' LKŽe, DrskŽ 361, stancija (Polish stancja) ‘living room' LKŽe.

Names of porches form a group of nine terms and four of them are generic names: budarka (Polish budować) LKA I 40, sienius (Polish sień) LKŽe, LKA I 40, pavietis (Belarusian naвeu,b) LKŽe, gonkas (Polish ganek) LKŽe, LKA I 39, KpŽ 703, LzŽ 83. The term sienius also is used to name a specific concept - a porch of non-representative house side: sienius (Polish sień) LKŽe, LKA I 40. The polysemous term gonkos and its variation gonkai according to construction features denote four types of porches: gonkos 'porch with glazed walls' LKA I 39, gonkos 'closed type glazed porch' LKA I 39, gonkos 'open type porch without windows' LKA I 40, gonkai 'decorated glazed porch' LKA I 39.

In the group of names of rooms the majority of terms are used to denote utility rooms (5 terms): bakava (Polish bokówka Fraenkel, 1962, p. 30) 'poor room for cooking, sleeping or storage' LKŽe, kamurka (Polish komórka, Russian каморка) 'small dark pantry' LKŽe, katukas (Belarusian komyx, Polish kotuch) 'small pantry, foyer' LKŽe, špirka (Polish szpyrka, szperka) 'small, poor pantry' LKŽe, špižarna (Polish spizarnia) 'pantry' LKŽe. Some of the mentioned terms have more than one meaning: kamurka is used to denote poor house and lavatory, bakava has an additional meaning of 'living room'. Katukas mostly is used to denote farm buildings and their parts - stall, roost, cowshed, and shed. The guest room is denoted by four synonymous terms of Slavic origin: seklyčia (Belarusian святліия, Polish świetlica) LKŽe, DrskŽ 361, pakajus (Polish pokój) LKŽe, KaltŽ 197, LzŽ 181, alkierius (Polish alkierz) LKŽe, kamara (Russian комора, Polish komora Фасмер, 1986, p. 305) LKŽe. The terms alkierius and kamara are also used to name other types of rooms. Alkierius denotes a bedroom, kamara has additional meanings 'living room' and 'pantry'. Also this term denotes house side and entrance of the bathhouse. Three groups of terms consisting of three terms each are used to denote living room, bedroom, and attic room: bakava (Polish bokówka 
Fraenkel, 1962, p. 30) 'living room' LKŽe, stancija (Polish stancja) 'living room' LKŽe, kamara (Russian комора, Polish komora Фасмер, 1986, p. 305) 'living room’ LKŽe, LzŽ 104; alkierius (Polish alkierz) 'sleeping room' LKŽe, gryčia (Belarusian грыдніu,a LKA I 34) 'sleeping room' LKŽe, kamara (Russian комора, Polish komora Фасмер, 1986, p. 305) 'sleeping room' LKŽe; salka (Polish salka) 'attic room' LKŽe, DrskŽ 315, etažas (Russian этаж RLKŽ, 2003, p. 909) 'attic room' LzŽ 73, viškos (Belarusian выıккi) 'attic room' LKŽe. The term viškos is also used to denote attic spaces of farm building and porch: viškos (Belarusian вышкi) 'room above barn ceiling' LKŽe; 'porch attic' LKŽe. Two synonyms name a corridor: būda (Belarusian $6 y \partial a$, Polish $b u d a$ ) LKŽe, sienis (Polish sień) LKŽe, LKA I 39, LzŽ 233. Cellar is denoted by the term sklepas (Polish sklep) LKŽe, DrskŽ 331, KaltŽ 277, LzŽ237, ZanavŽ 3 85. One term is used to denote storage room and one term - kitchen: kamara (Russian комора, Polish komora Фасмер, 1986, p. 305) LKŽe, DrskŽ 134, KzRŽ I, ZanavŽ 1604 , kukné (Belarusian кухня, Polish kuchnia) LKŽe.

In Lithuanian folk terminology of building, Slavic terms are also widely used to denote farm buildings ( 24 terms) and their parts ( 56 terms). The main farm building of traditional Lithuanian homestead is grannary. This building serves as storage for grain, flour, farming goods, clothes and other goods, besides that some grannaries were used as dormitory for laborers. Only Lithuanian and German loanwords are used to denote this building while Slavic loanwords are used to denote parts of the grannary. A pair of terms name the annex: prizba (Belarusian $n p b l 36 a$ ) LKA I 48, gonkas (Polish ganek) LKA I 48. Group of names of grannary ceiling consists of seven terms: grédai (Russian гряда, Belarusian градa) LKA I 49, pacesas (Belarusian naщёс LKA I 36) LKA I 49, padlaga (Polish podłoga, Belarusian падлогa) LKA I 49, staliavonia LKA I 49, ščitas (Polish szczyt) LKA I 49, viškos (Belarusian выıкi) LKŽe, palotai (Belarusian палаці) LKA I 49.

Barn is a traditional farm building for grain storage and threshing. A Lithuanian barn is characterized by a rectangular plan, four-slope or two-slope rafter or spur-type construction roof and wide attic for storage of instruments, firewood and other goods (TechE II, 2003, p. 506). Only terms of Lithuanian, Latvian and German origin are used to denote this building. Slavic loanwords are used only to denote annexes and parts of a barn. Barn space has three names: pravarine (Polish przeworzyna LKŽe) DūnŽ 279, pamastas (old Russian помость Фасмер, 1987, p. 323, Polish pomost) LKŽe, LKA I 54, takas (Belarusian, Russian mok, Polish tok) LKŽe, LKA I 54. The term vazaune (Polish wozownia, Belarusian вазоц̆ня) LKŽe is polysemous and also is used to denote place for storing hay. A pair of terms name the place for stacking crop or hay: préslas (Belarusian dialect. прясла, прасла) LKA I 55, LKŽe, zvenas (Belarusian звяно) LKŽe, LKA I 55. The place between roof holding pillar and back wall is called by a metaphoric term kišenè (Polish kieszeń Fraenkel, 1962, p. 259) LKA I 55. Metaphorical meaning could have occurred by meaning transfer according to analogy of function: 
kišene 'garment pouch for keeping small things' LKŽe. Barns usually were built with drying rooms, called sušnia (Belarusian сушня) LKA I 65. Such closed-type rooms were built from rounded logs and had individual ceiling and stove. There are three synonymous terms which name the annex for stacking crop two synonymous terms: tristinka (Belarusian трысиень) LKA I 57, vazaune (Belarusian вазоуня) LKA I 57. Term trustienis (Belarusian трысиень) LKŽe denotes entrance of an annex.

Group of six synonymous terms name a hay barn: adryna (Belarusian aдрына, Polish odryna) LKA I 57, kaladnykas (Belarusian холодник, Polish chłodnik) LKA I 57, padake (Polish poddasze) LKA I 57, pavietis (Belarusian naвeu) LKA I 57, salošius (Russian dial. сала́m СРНГ 36, 2002, p. 60, Polish szałas ЕСУM, 2006, p. 168) LKA I 57, šopas (Polish szopa LKŽe) LKA I 57. Term salošius also has the meaning 'shed for keeping hay'. Abundance of synonyms can be explained by the variety of buildings. According to ethnographers, separate buildings for keeping hay were quite rare and mostly annexes or sheds build on the side of the animal barn were used for hay storage (LKA I, 1977, p. 57).

Two Slavisms are used to name a bathhouse: bane (Russian, Belarusian dialect. баня) LKA I 58 and lazne (Polish łaźnia, Belarusian лазня) LKA I 58, LKŽe. Three terms name an entrance of a bathhouse: sienis (Polish sień) LKŽe, LKA I 58, trusienis (Belarusian трысиень) LKA I 58, kamara (Russian комора, Polish koтоra Фасмер, 1986, p. 305) LKA I 58.

A group of ten terms name animal barns and three of them are used as generic terms: abarès (Polish obora LKŽe) LKA I 50, stainia (Belarusian стайня, Polish stajnia) LKŽe, stodas (Belarusian stado Fraenkel, 1965, p. 910) LKŽe. Regional usage is a characteristic peculiarity of names of animal barns. For example, Lithuanian term tvartas is widely spread and is used in all regions of Lithuania. A term of Latvian origin $k \bar{u} t \dot{e}$ commonly is used in northern part of Lithuania, gurbas - in eastern north area, German staldas - in southern part of Samogitia, etc. (Sabaliauskas, 1970, pp. 30-49). Terms of Slavic origin also have a regional character: abares is mainly used in Samogitia, stainia - in the eastern and western regions of Aukštaitija, stodas - in the southern part of Aukštaitija.

Terms abares and stainia are also used to denote specific concepts. Specific terms name four types of animal barns: stable, cowshed, piggery, and roost: abarai (Belarusian абора, Polish obora) 'stables' LKA I 51, kaniušnia (Belarusian канюшня) DrskŽ 136, LKA I 51, stainia (Belarusian cmaŭня, Polish stajnia) LKŽe, LKA I 51, DrskŽ 346, ZanavŽ 3 161; abarès (Belarusian aбopa, Polish obora) 'cowshed' LKA I 50, valaunios (Belarusian валоуня) LKA I 50; kaniūkšle (Belarusian канюшня, Russian конюшня LKA I 51) 'pigsty' LKŽe; katukas (Belarusian komyx, Polish kotuch) 'chicken hood' LKŽe, KaltŽ 103.

Term katukas is polysemous and also denotes a stall of an animal barn. These terms can be treated as generic while specific terms indicate purpose aspects of an ani- 
mal barn: svinarnykas (Belarusian свінарнік) 'place in the barn where pigs are kept, pigsty' LKA I 52, siopa (Polish szopa) 'roof space on animal barn where hay is kept' LKA I 57. Place where hens are kept is denoted by three synonymous terms: katukas (Belarusian komyx, 1. kotuch LKŽe) LKA I 52, KaltŽ 103, kuratnykas (Belarusian куратнік) LKA I 52, kurnykas (Belarusian куратнік) LKA I 52.

There are nine synonymous terms which name annexes and sheds: $b \bar{u} d a$ (Belarusian buda Fraenkel, 1962, p. 61) KzRZ̆ I 88, ZanavŽ 1 182, adryna (Belarusian aдрына, Polish odryna LKA I 57) LzŽ 18, balaganas (Russian балаган TŽŽ 2005) ZanavŽ 1 101, katukas (Belarusian komyx, Polish kotuch) LKŽe, pavietè (Belarusian naвeu,b) LKŽe, salošius (Russian dial. салám СРНГ 36, 2002, p. 60, Polish sałasz ЕСУM, 2006, p. 168) LKŽe, šapas (Polish szopa) LKŽe, pašopé (Polish podszopie) LKŽe, DrskŽ 250, šiopa (Polish szopa) LKŽe, ZanavŽ 3 281. Term šiopa is also used as a specific term and denotes a shed where thresher is kept. Other specific terms name sheds according to their purpose, construction and place: lazaune (Polish wozownia) 'shed where cart, harness and tools are kept' LKŽe, šiopa (Polish szopa) 'shed for keeping thresher and other agricultural mashines' LKŽe, šopa (Polish szopa) 'shed for keeping hay, flax' LKŽe, važnyčia (Belarusian вазніияа, Polish woźnica) 'shed for keeping cart' LKŽe; baragas (Belarusian aбapoz) 'shed on four poles for keeping hay, straw and peat' LKŽe; palagas (Russian полог, Belarusian полаг) 'barn shed' LKŽe. Other farm buildings are denoted by these three terms: grinčia (Belarusian грыдніца LKA I 34) 'building where potatoes are kept' LKŽe, kabure (Russian кобуpa) 'plank building for storage' LKŽe, šopa (Polish szopa) 'shed' LKŽe.

Majority of Slavic folk terms according to norms of the standard Lithuanian language are considered as barbarisms, e.g.: $\times^{7}$ budavone $\mathrm{LKŽe}$, $\times$ kamara LKŽe, $\times k u k n e$ LKŽe, $\times$ salošius LKŽe, $\times$ seklyčia LKŽe, $\times$ šopa LKŽe. Some terms are used in the standard Lithuanian language and in scientific terminology; for example, in fields of construction and rail transport: būda LKŽe - būdele 'cab' STŽ, kišenè LKŽe balasto kišenè 'ballast pocket' AGTTŽ, mūras LKŽe - mūras 'stone wall' STŽ.

\section{Conclusions}

1. Folk terminology of building is a broad, interesting and miscellaneous layer of folk terminology and is characterized by regional use, variety of expression, figurativeness, abundance of synonyms and polysemy. Terms of Slavic origin amount to a significant part of Lithuanian folk terminology of building and make the largest group of borrowed terminology in this field.

\footnotetext{
${ }^{7}$ Cross sign in Dictionary of the Lithuanian Language is used to mark irregular words.
} 
2. Terms of Slavic origin are used to denote almost all buildings of a traditional Lithuanian homestead and majority of them are names of farm buildings. Slavisms are used to denote generic and specific concepts. Specific terms name houses according to the quality, construction and size aspects. Animal barns are denoted by purpose and sheds by purpose, construction and dependence aspects.

3. A significant part of traditional buildings and their parts have more than one name of Slavic origin. Synonymous naming is a characteristic peculiarity of one third part of the discussed concepts. Part of synonymous terms can be treated as partial synonyms as they originated from different ethnographic regions of Lithuania and name different buildings.

4. Few terms can be identified as metaphoric. Poor house, big house and place where crop is kept are denoted by such names as animal barn, pantry, drive-in pub, pocket. Metaphorical transfer of the names according to emotional associations, external similarity or similarity of function is typical.

5. Almost half of the terms have more than one meaning. Polysemous terms name different constructions: building and room, part of building and room; less frequently they denote buildings or rooms of different purpose. Naming generic and specific concepts or denoting building and part of same building is not a prevalent type of polysemy of researched terminology.

6. Slavic folk terms that correspond the norms of the standard language are important sources for scientific terminology.

\section{Primary sources}

DrskŽ - Naktinienè Gertrūda, Paulauskienè Aldona, Vitkauskas Vytautas. Druskininku tarmès žodynas, Vilnius: Mokslas, 1988.

DūnŽ - Vitkauskas Vytautas. Šiaurès rytu dūnininku šnektų žodynas, Vilnius: Mokslas, 1976.

KltŽ - Vilutytė Angelè. Kaltanènu šnektos žodynas, Vilnius: Lietuvių kalbos institutas, 2008.

KpŽ - Vosylytė Klementina. Kupiškènu žodynas (A-H), Vilnius: Lietuvių kalbos institutas, 2007.

KzRŽ I - Pupkis Aldonas. Kazlų Rūdos šnektos žodynas (A-M), Vilnius: Lietuvių kalbos institutas, 2008.

LKA I - Lietuviu kalbos atlasas. T. 1: Leksika, Vilnius: Mokslas, 1977.

LKŽe - Lietuviu kalbos žodynas (elektroninio varianto I leidimas, www.lkz.lt), Vilnius: Lietuvių kalbos institutas, 2005. 
LzŽ - Petrauskas Jonas, Vidugiris Aloyzas. Lazūnų tarmės žodynas, Vilnius: Mokslas, 1985.

ZanavŽ 1-3 - Zanavykų šnektos žodynas. T. 1-3, Vilnius: MELI, 2003-2006.

\section{Abbreviations}

AGTTŽ 2006 - Aiškinamasis geležinkelių transporto terminų žodynas: terminai lietuvių, anglų, vokiečiu ir rusų kalbomis, Vilnius: Lietuvos geležinkeliai, 2006.

LEB 1964 - Lietuviu etnografijos bruožai, Vilnius: Valstybinè politinès ir mokslinès literatūros leidykla, 1964.

Med - Medega statant trobas. - Auszra, 1884, Nr. 1-2, P. 56-59.

RLKŽ 2003 - Lemchenas Chackelis. Rusų-lietuvių kalbų žodynas, Vilnius: Mokslo ir enciklopedijų leidykla, 2003.

STŽ 2002 - Statybos terminu žodynas, Vilnius: Lietuvos mokslas, 2002.

TechE II 2003 - Technikos enciklopedija 2, Vilnius: Mokslo ir enciklopedijų institutas, 2003.

TŽŽ 2005 - Tarptautinių žodžių žodynas, Vilnius: Alma littera, 2005.

Uk - Ukinịkas: lietuviszkas laikrasztis, paskirtas reikalams ukinįkų, Ragainè, 1880-1905.

ЭСБМ 1985 - Этымалагічны слоўнік беларускай мовы 3, Мінск: Навука і тэхніка, 1985.

СРНГ 2002 - Словарь русских народных говоров 36, Санкт-Петербург: Наука, 2002.

ЕСУМ 2006 - Етимологічний словник украӥнської мови 5, Київ, 2006.

ЭССЯ 1983 - Этимологический словарь славянских языков 9, Москва: Наука, 1983.

\section{Bibliography}

Aiškinamasis geležinkelių transporto terminų žodynas: Terminai lietuvių, anglų, vokiečių ir rusų kalbomis [AGTTŽ]. (2006). Vilnius: Lietuvos geležinkeliai.

Fraenkel, E. (1962). Litauisches Etymologisches Wörterbuch von Ernst Fraenkel (Vol. 1). Heidelberg: E. Carl Winter, Universitätsverlag, Vandenhoeck \& Ruprecht.

Fraenkel, E. (1965). Litauisches Etymologisches Wörterbuch von Ernst Fraenkel (Vol. 2). Heidelberg: E. Carl Winter, Universitätsverlag, Vandenhoeck \& Ruprecht.

Lemchenas, C. (2003). Rusų-lietuvių kalbų žodynas [RLKŽ]. Vilnius: Mokslo ir enciklopedijų leidykla.

Lietuvių etnografijos bruožai [LEB]. (1964). Vilnius: Valstybinè politinès ir mokslinès literatūros leidykla.

Lietuvių kalbos atlasas [LKA I]. (1977) (Vol. 1, Leksika). Vilnius: Mokslas.

Lietuvių kalbos žodynas [LKŽe]. (2005). Vilnius: Lietuvių kalbos institutas. (Elektroninio varianto I leidimas, www.lkz.lt)

Medega statant trobas [Med]. (1884). Auszra, (1-2), 56-59. 
Naktinienè, G., Paulauskienè, A., \& Vitkauskas, V. (1988). Druskininkų tarmés žodynas [DrskŽ]. Vilnius: Mokslas.

Petrauskas, J., \& Vidugiris, A. (1985). Lazūnų tarmès žodynas [LzŽ]. Vilnius: Mokslas.

Pupkis, A. (2008). Kazlų Rūdos šnektos žodynas (A-M) [KzRŽ I]. Vilnius: Lietuvių kalbos institutas.

Sabaliauskas, A. (1970). Iš baltų kalbų gyvulininkystės terminologijos istorijos. Lietuvių kalbotyros klausimai, 12, 7-81.

Statybos terminu žodynas [STŽ]. (2002). Vilnius: Lietuvos mokslas.

Stunžinas, R. (2001). Statybos liaudies terminai: Daktaro disertacija. Vilnius: Lietuvių kalbos institutas.

Šalkauskis, S. (1991). Raštai 2. Vilnius: Mintis.

Tarptautinių žodžiu žodynas [TŽŽ]. (2005). Vilnius: Alma littera.

Technikos enciklopedija 2 [TechE II]. (2003). Vilnius: Mokslo ir enciklopedijų institutas.

Ukinįkas: lietuviszkas laikrasztis, paskirtas reikalams ukinįku [Uk]. (1880-1905). Ragainè.

Vilutytė, A. (2008). Kaltanėnų šnektos žodynas [KltŽ]. Vilnius: Lietuvių kalbos institutas.

Vitkauskas, V. (1976). Šiaurès rytu dūnininku šnektǔ žodynas [DūnŽ]. Vilnius: Mokslas.

Vosylytė, K. (2007). Kupiškènų žodynas (A-H) [KpŽ]. Vilnius: Lietuvių kalbos institutas.

Zanavykų šnektos žodynas [ZanavŽ 1-3]. (2003-2006) (Vols. 1-3). Vilnius: MELI.

Етимологічний словник української мови 5 [ЕСУМ]. (2006). Київ.

Словарь русских народных говоров 36 [СРНГ]. (2002). Санкт-Петербург: Наука.

Фасмер, М. (1973). Этимологический словарь русского языка (Vol. 4). Москва: Прогресс.

Фасмер, М. (1986). Этимологический словарь русского языка (2nd ed., Vol. 2). Москва: Прогресс.

Фасмер, М. (1987). Этимологический словарь русского языка (2nd ed., Vol. 3). Москва: Прогресс.

Этимологический словарь славянских языков 9 [ЭССЯ]. (1983). Москва: Наука.

Этымалагічны слоўнік беларускай мовы 3 [ЭСБМ]. (1985). Мінск: Навука і тэхніка.

\section{Bibliography (transliteration)}

Aiškinamasis geležinkelių transporto terminų žodynas: Terminai lietuvių, anglų, vokiečiu ir rusų kalbomis [AGTTŽ]. (2006). Vilnius: Lietuvos geležinkeliai.

Ėtymalahichny sloŭnik belaruskaĭ movy 3 [E்SBM]. (1985). Minsk: Navuka i tèkhnika.

Ėtimologicheskiŭ slovar' slavianskikh iazykov 9 [ЭССЯ]. (1983). Moskva: Nauka.

Etymolohichnyı̆ slovnyk ukraïns'koï movy 5 [ESUM]. (2006). Kyïv.

Fasmer, M. (1973). Etimologicheskiŭ slovar' russkogo iazyka (Vol. 4). Moskva: Progress.

Fasmer, M. (1986). Étimologicheskiǔ slovar' russkogo iazyka (2nd ed., Vol. 2). Moskva: Progress. 
Fasmer, M. (1987). Étimologicheskiǔ slovar' russkogo iazyka (2nd ed., Vol. 3). Moskva: Progress. Fraenkel, E. (1962). Litauisches Etymologisches Wörterbuch von Ernst Fraenkel (Vol. 1). Heidelberg: E. Carl Winter, Universitätsverlag, Vandenhoeck \& Ruprecht.

Fraenkel, E. (1965). Litauisches Etymologisches Wörterbuch von Ernst Fraenkel (Vol. 2). Heidelberg: E. Carl Winter, Universitätsverlag, Vandenhoeck \& Ruprecht.

Lemchenas, C. (2003). Rusų-lietuvių kalbų žodynas [RLKŽ]. Vilnius: Mokslo ir enciklopedijų leidykla.

Lietuvių etnografijos bruožai [LEB]. (1964). Vilnius: Valstybinè politinės ir mokslinès literatūros leidykla.

Lietuvių kalbos atlasas [LKA I]. (1977) (Vol. 1, Leksika). Vilnius: Mokslas.

Lietuvių kalbos žodynas [LKŽe]. (2005). Vilnius: Lietuvių kalbos institutas. (Elektroninio varianto I leidimas, www.lkz.lt)

Medega statant trobas [Med]. (1884). Auszra, (1-2), 56-59.

Naktinienè, G., Paulauskienė, A., \& Vitkauskas, V. (1988). Druskininkų tarmés žodynas [DrskŽ]. Vilnius: Mokslas.

Petrauskas, J., \& Vidugiris, A. (1985). Lazūnų tarmès žodynas [LzŽ]. Vilnius: Mokslas.

Pupkis, A. (2008). Kazlų Rūdos šnektos žodynas (A-M) [KzRŽ I]. Vilnius: Lietuvių kalbos institutas.

Sabaliauskas, A. (1970). Iš baltų kalbų gyvulininkystès terminologijos istorijos. Lietuvių kalbotyros klausimai, 12, 7-81.

Slovar' russkikh narodnykh govorov 36 [SRNG]. (2002). Sankt-Peterburg: Nauka.

Statybos terminuz žodynas [STŽ]. (2002). Vilnius: Lietuvos mokslas.

Stunžinas, R. (2001). Statybos liaudies terminai: Daktaro disertacija. Vilnius: Lietuvių kalbos institutas.

Šalkauskis, S. (1991). Raštai 2. Vilnius: Mintis.

Tarptautinių žodžių žodynas [TŽŽ]. (2005). Vilnius: Alma littera.

Technikos enciklopedija 2 [TechE II]. (2003). Vilnius: Mokslo ir enciklopedijų institutas.

Ukinįkas: lietuviszkas laikrasztis, paskirtas reikalams ukinįku [Uk]. (1880-1905). Ragainè.

Vilutytė, A. (2008). Kaltanènų šnektos žodynas [KltŽ]. Vilnius: Lietuvių kalbos institutas.

Vitkauskas, V. (1976). Šiaurès rytu dūnininkų šnektu žodynas [DūnŽ]. Vilnius: Mokslas.

Vosylytè, K. (2007). Kupiškènų žodynas $(A-H)$ [KpŽ]. Vilnius: Lietuvių kalbos institutas.

Zanavykǔ šnektos žodynas [ZanavŽ 1-3]. (2003-2006) (Vols. 1-3). Vilnius: MELI. 


\section{Ludowe nazwy pochodzenia słowiańskiego tradycyjnych litewskich budynków i ich części}

\section{Streszczenie}

Celem artykułu jest dokonanie przeglądu nazw ludowych pochodzenia słowiańskiego, odnoszących się do budynku i jego części, oraz ustalenie semantycznych relacji terminów - synonimia i polisemia. Artykuł dotyczy ponad 130 slawizmów; materiał został zebrany na podstawie głównych źródeł języka mówionego i nazewnictwa ludowego - słowników ogólnych oraz słowników i atlasów gwarowych. Ludowe nazewnictwo dotyczące budynków stanowi szeroką, interesującą i różnorodną warstwę terminologii ludowej, przy czym cechuje się regionalnym użyciem, zmiennością wyrazu, figuratywnością, obfitością synonimów i polisemią. Terminy pochodzenia słowiańskiego stanowią znaczącą część litewskiej terminologii ludowej, odnoszącej się do budynków, i są największą grupą zapożyczonej terminologii z tego zakresu.

Terminy pochodzenia słowiańskiego używane są do nazywania prawie wszystkich budynków tradycyjnego litewskiego gospodarstwa. Znaczna ich część ma więcej niż jedną nazwę pochodzenia słowiańskiego. Niektóre terminy pochodzenia słowiańskiego można określić jako metaforyczne lub jako typowo metaforyczne przeniesienie nazwy w zgodzie ze skojarzeniami emocjonalnymi, podobieństwem zewnętrznym bądź podobieństwem pełnionych funkcji. Prawie połowa terminów ma więcej niż jedno znaczenie. Polisemiczne terminy nazywają różne konstrukcje: budynek i pokój, część budynku i pokoju; rzadziej oznaczają budynki lub pokoje o odmiennym przeznaczeniu. Nazewnictwo pojęć ogólnych i szczegółowych oznaczających budynek i jego części nie stanowi przeważającego typu polisemii w badanej terminologii.

Słowa kluczowe: litewska terminologia ludowa; terminy pochodzenia słowiańskiego; nazwy budynków; synonimia; polisemia; terminy metaforyczne 


\title{
Folk terms of Slavic origin for traditional Lithuanian buildings and their parts
}

\begin{abstract}
The aim of this article is to give an overview of folk terms of Slavic origin naming houses and their parts and to identify semantic relations of terms - synonymy and polysemy. The article deals with more than 130 Slavisms, the material has been gathered from the main sources of spoken language and folk terminology - common dictionaries, dictionaries and atlases of dialects. Folk terminology of building is a broad, interesting and miscellaneous layer of folk terminology and is characterized by regional use, variety of expressions, figurativeness, abundance of synonyms and polysemy. Terms of Slavic origin amount to a significant part of Lithuanian folk terminology of building and make the largest group of borrowed terminology in this field.

Terms of Slavic origin are used to denote almost all buildings of a traditional Lithuanian homestead. A significant part of traditional buildings and their parts have more than one name of Slavic origin. A few terms of Slavic origin can be identified as metaphoric and metaphorical transfer of the names according to emotional associations, external similarity or similarity of function is typical. Almost half of terms have more than one meaning. Polysemous terms name different constructions: building and room, part of building and room; less frequently they denote buildings or rooms of different purpose. Naming generic and specific concepts or denoting building and part of same building is not a prevalent type of polysemy of researched terminology.
\end{abstract}

Keywords: Lithuanian folk terminology; terms of Slavic origin; names of buildings; synonymy; polysemy; metaphorical terms

Correspondence: Robertas Stunžinas, Mykolas Romeris University, Vilnius, e-mail: robertas.stunzinas@gmail.com

Support of the work: This work was carried out from author's own resources. Competing interests: The author declares that he has no competing interests. 